\title{
Antecedents of Turnover Intentions: Health Care Staff in Saudi
}

\section{Arabia}

\author{
Abdelmohsen A. Nassani ${ }^{1 *}$ Atheer A. Alzamami ${ }^{\text {*** }}$ Haya A. Bin Salamah $^{1 * * *}$ Nada E. Alkhamis ${ }^{1 * * *}$ \\ 1. Department of Management, College of Business Administration, King Saud University, P.O. Box71115, \\ Riyadh 11587, Saudi Arabia \\ * Nassani@ksu.edu.sa_**Atheer.Alzamami@gmail.com \\ ***Hayasalamah@gmail.com ****Nadalkhamis@gmail.com
}

\begin{abstract}
This research aims to investigate the antecedents of turnover intentions and the relationship between work stress and job satisfaction among health care staff in Saudi Arabia. Data were collected via an online survey, and the sample consists of 143 health care staff both medical and non-medical staff in Saudi Arabia. Results generated using Statistical Package for Social Science (SPSS). The results show there is a significant positive effect between work stress and turnover intention, and a significant negative effect between job satisfaction and turnover intentions. The results also show that there is significant positive relationship between work stress and job satisfaction.
\end{abstract}

Keywords: Turnover intentions, Work stress, Job satisfaction, Health care staff.

DOI: $10.7176 / \mathrm{EJBM} / 13-8-18$

Publication date: April 30th 2021

\section{Introduction}

Nowadays, organizations are suffering from a shortage of workers and a high level of intention to leave the job. The last 10 years reached the highest rate of employee turnover globally according to (Boss 2018). Health workers are one of the most important building blocks of the health system. Healthcare staff turnover intention remains a global issue, which considered globally as one of the organizations' most important issues. High turnover rate contributes to the shortfalls and unbalanced distribution of health personnel in the health workforce. Saudi Arabia health sector is also facing a high turnover rate among workers according to the Annual report of Ministry of health that turnover rates in 2019 reached $4 \%$ from a total of 274,637 medical and non-medical staff. Thus, it indicates the need for investigating the motives behind this high turnover levels and exert more efforts in retaining health sector workers.

Organizations can become more successful, productive, build brand loyalty, do better work, and achieve higher success through recognizing their human aspect. Consequently, it is believed that organizations that better manage their human capital would have a higher success rate. Human resource management (recruitment, training, and career development) would enable workers to increase their quality of work. One of the parameters for assessing organizational efficiency, according to (Ivancevic and Konopaske 2013) is turnover. Employee turnover has a negative effect on the company's operations such as lowering sales, decrease customers' satisfaction, high training costs, and loss of time and effort for doing recruitment process again. Thus, employee turnover will affect the productivity and performance of the whole organization (Saragih, Prasetio, Luturlean 2020). It is important for organizations to investigate the factors that affect employee's intention to leave. According to the literature, turnover intention is strongly related to job satisfaction and work stress, using that relationship can make a great change in the future of health sector. This study aims to examine the antecedents of turnover intention among health care staff in Saudi Arabia.

\section{Theoretical Background and Hypothesis Development}

\subsection{Relationship between work Stress and turnover intention}

The likelihood of an employee leaving an organization is defined as turnover intention (Grandey, 2000). Turnover intentions according to Tett \& Meyer, (1993) can be defined as "the conscious and deliberate willingness to leave the organization" it considered as one of the significant challenge's organizations faced. Turnover intention has been shown to be strongly associated with actual turnover in the literature (Han and Jekel, 2011; Shahnawaz and Jafri, 2009). Work stress considered a critical factor that may be the reason behind employee intention to leave the organization. Ferdian, Luturlean, Zhafira, and Izumi (2020) found that work stress has a positive effect on turnover intention. In addition, many other studies found that work stress increases turnover intention (Arshadi and Damiri, 2013; Jou, Kuo, and Tang,2013; Elci, Sener, Aksoy, and Alpkan, 2012). Liu, Zhu, Wu, and Mao (2019) indicate that workload and negative emotions as factors that cause a high level of work stress will result in a high level of 
turnover intention. Moreover, Steinmetz et al(2014) noticed that working time is a considerable and significant factor that affects the intention of health workforce to stay or leave their job. According to Ferdian et al. (2020) workers who suffer from high work stress they tend to have a great intention to leave the job. Since organizations are seeking for their best, which causes a challenging and stressful work environment so they must improve their selection process because most of the stress is due to individual characteristics (Ferdian et al. , 2020). Improving the selection process and organization management system can reduce turnover cost according to O'Connell and Kung (2007). Ferdian et al. (2020) added that providing employees a flexible work hour will reduce employees' work stress thus their intention to quit the job. Saragih et al. (2020) suggest that organization should create programs that give employees the opportunity to be involved in the job. In addition, providing a flexible work environment and an attractive reward in order to manage work stress and preventing workers' intention to leave their jobs. Based on those findings, the first hypothesis is proposed:

Hypothesis 1: Work stress will positively influence turnover intentions of health care staff.

\subsection{Relationship between job satisfaction and turnover intention}

According to (Diestel, Wegge, and Schmidt, 2014) Job satisfaction is a significant predictor of employee turnover. Job satisfaction is described by (Kreitner and Kinicki, 2010) as "an affective or emotional response to various aspects of one's job that represents the degree to which one enjoyed one's job". Job satisfaction, according to Hoppock (1935), is described as a combination of cognitive, physiologic, and environmental factors that cause an individual to be satisfied or dissatisfied with his or her work. Vroom (1964) claims that employee job satisfaction is influenced by the subjective nature of the work they do. Workers will have a positive attitude about their job if they are satisfied with it, and vice versa (Armstrong, 2006). The job satisfaction study examines ways to discourage voluntary job turnover of employees (Diestel et al., 2014; Nobuo, 2014). To reduce turnover organizations should implement strategies to improve worker satisfaction, according to Cho, Lee, Mark, and Yun (2012). When workers have negative emotional reactions to hygiene factors on the employment, according to Pietersen and Oni (2014), job dissatisfaction drives employee turnover. Similarly, Richardson (2014) discovered that when performance and motivation are high, so job satisfaction is high. In the turnover literature, the relationship between work satisfaction and voluntary turnover has received considerable attention. The most dominant result that the relationship between job satisfaction and turnover is that there is a correlation in which staff who are dissatisfied are more likely to quit than those who are satisfied (Sukriket, 2015). Woolworth (2016) found that executives need to realize that job satisfaction needs to be improved. Moreover, it is necessary to retain trained staff, enhance teaching, and reduce the costs of turnover. Maslow (1970) indicated that employees still want more from their managers. If an employee goes up and promoted in the workplace, the level of satisfaction of employees will increase (Cote, 2017). An employee, therefore, who achieving self-actualization can have a high level of job satisfaction regardless of their jobs. Conant (2017) noted that dissatisfaction and wanting to leave the job are related to that employees are not getting a clear sense of work accountability. However, Ololo, Kalifa, and Tafese (2016) found that once an employee is serving for a long time, he is less willing to leave the company. Ferdian et al. (2020) found that when organizations cares for their employee's well-being, an employee in return will be loyal and less considering quit. Huang, and Chih-Hao, (2016) found in their study that there is a strong negative relationship between job satisfaction and turnover intentions. Moreover, they found that low job satisfaction may be an indication that an employee is intending to leave. Thus, employee turnover will be reduced if managers improve employee job satisfaction. Consequently, the second hypothesis is suggested:

Hypothesis 2: Job satisfaction will negatively influence turnover intentions of health care staff.

\subsection{Relationship between work stress and job satisfaction}

Mc Grath, (1976) define's stress as environmental condition where a person is in demand of performing tasks that exceed his ability and qualifications, under a situation where he or she anticipate a major difference in the rewards from meeting the demand versus not meeting it. Whereas Ahmadi and Alireza, (2007) attribute's job stress is due to organizational sources, conflict with demands and pressures, long work hours, lack of support from supervisors and colleagues, lack of organizational support and organizational change. According to Venkataraman and Ganapthi, (2013) one of the most significant workplace health risks for employees in developed countries is work stress . Work stress levels are believed to have an impact on job satisfaction. Many previous studies have been confirmed a significant and negative relationship between work stress levels and job satisfaction. According to Venkataraman and Ganapthi, (2013) job stress sources of workload and role conflict has a negative effect on employee job satisfaction. While Fletcher \& Payne (1980) have found that low level of satisfaction can be a cause of stress, while high level of satisfaction can lighten the effects of stress, it means that both job stress and job 
satisfaction are interrelated. Furthermore, viewing the consequences that will likely result from experiencing work stress, high stress and strain are related to lower job satisfaction levels (Troesch and Bauer, 2017). In general, Stanton, Bachiochi, Robie, Perez, and Smith, (2002) describe's job stress as a predecessor of job satisfaction, and the two constructs have been treated as related yet distinct. These studies endorsed the concept of the inverse correlation between work stress and job satisfaction. Based on previous studies, our third hypothesis is proposed: Hypothesis 3: Work stress will negatively affect health care staff's job satisfaction.

\section{Methodology \\ 3.1. Sample and Data Collection}

Data were collected via an online survey, which was conducted among health care workers in Saudi Arabia. Whereas, the health care workers refer to medical staff such as doctors, nurses, pharmacists, etc. In addition to non-medical staff including managers and support workers.

The questionnaire consists of 40 items that measure work stress, job satisfaction, and turnover intentions. Additionally, four questions to determine the demographic characteristics of the respondents (age, type of work, work hours, and years of experience). The sample size was 163 however 20 respondents were eliminated due to unseriousness and fairness in answering the questionnaire. Thus, the study consist of 143 respondents working in the health sectors in Saudi Arabia. Majority of the respondents were between 30-39 years with 46.9\% followed by 20-29 years with $30.1 \%$. In term of type of job medical staff were $58 \%$ while non-medical staff were $42 \%$. Moreover, $58 \%$ are working 8 hours per day or less while $42 \%$ work more than 8 hours per day. The analysis of the results also reveals that the highest percent of years of experience is more than 10 years with $42.7 \%$. More details for data respondents are clarified in Table1.

Table 1. Demographic Characteristics

\begin{tabular}{|c|c|c|c|}
\hline Characteristics & Category & Number & Percentage \\
\hline \multirow[t]{4}{*}{ Age } & 20-29 Years & 43 & $30.1 \%$ \\
\hline & 30-39 Years & 67 & $46.9 \%$ \\
\hline & 40-50 Years & 26 & $18.2 \%$ \\
\hline & $>50$ Years & 7 & $4.9 \%$ \\
\hline \multirow[t]{2}{*}{ Job Type } & Medical staff & 83 & $58.0 \%$ \\
\hline & Non-medical staff & 60 & $42.0 \%$ \\
\hline \multirow[t]{2}{*}{ Work Hours } & $\leq 8$ Hours & 83 & $58.0 \%$ \\
\hline & $>8$ hours & 60 & $42.0 \%$ \\
\hline \multirow[t]{4}{*}{ Experience } & $<3$ years & 19 & $13.3 \%$ \\
\hline & 3-5 Years & 21 & $14.7 \%$ \\
\hline & 6-10 Years & 42 & $29.4 \%$ \\
\hline & $>10$ Years & 61 & $42.7 \%$ \\
\hline
\end{tabular}

Note. $\mathrm{N}=143$

\subsection{Measures}

A questionnaire consists of 40 items was developed to measure the study variable. Job satisfaction was measured with 12 items that developed by Paul E. Spector (1994) from job satisfaction survey will be used with 5-level Likert Scale where 1 is Completely Disagree and 5 is Completely Agree. Turnover intention was assessed with 7 
items developed depending on Turnover Intention Scale by Roodt (2004) Using 5 option Likert scale that 1 is Never whereas 5 is Always. Work stress measured with 21 items from Occupational Stress and will use 5-level Likert Scale 1 refer to Strongly Disagree while 5 is Strongly Agree. However, some of the phrases in the scales did not fit with the surveyed respondent, so, the researchers excluded some of them and restate and merged others to improve the quality of the scale.

\section{Analysis and Result}

The descriptive statistics and zero-order correlations among the study variables are presented in Table 2. According to Carver \& Nash, 2006 a correlation measures the relationship between variables. Turnover intention is significantly and negatively correlated with job satisfaction $(\mathrm{r}=-.258-, \mathrm{p}<.01)$, and significantly positive correlated with work stress $(\mathrm{r}=.226, \mathrm{p}<.01)$. Job satisfaction significantly positive correlated with work stress $(\mathrm{r}$ $=.299, \mathrm{p}<.01)$. Thus, two of the variables in our study were significantly correlated in the expected directions, according to correlation results while the third was significantly correlated in the opposite.

T-test were done to examine the effect of demographic profile on health care staff's turnover intention. It showed that age and work hours had a significant effect with turnover intention while type of job and experience were not significant. Turnover intention with age were significant at 0.050 while with work hours at 0.35 . Table 3

Table2: Descriptive statistics and zero-order correlation among the study variables

\begin{tabular}{|l|c|c|c|c|c|}
\hline Variable & Mean & SD & $\begin{array}{l}\text { Turnover } \\
\text { Intention }\end{array}$ & $\begin{array}{c}\text { Job } \\
\text { Satisfaction }\end{array}$ & $\begin{array}{c}\text { Work } \\
\text { Stress }\end{array}$ \\
\hline $\begin{array}{l}\text { Turnover } \\
\text { Intention }\end{array}$ & 3.05 & 0.77 & 1 & $-.258-^{* *}$ & $.226^{* *}$ \\
\hline Job Satisfaction & 2.92 & 0.68 & $-.258-* *$ & 1 & $.299^{* *}$ \\
\hline Work Stress & 3.16 & 0.48 & $.226^{* *}$ & $.299^{* *}$ & 1 \\
\hline
\end{tabular}

Note. $\mathrm{N}=143, * *$ Correlation is significant at the 0.01 level (2-tailed). $\mathrm{SD}=\mathrm{Standard}$ Deviation

Table 3. T-test

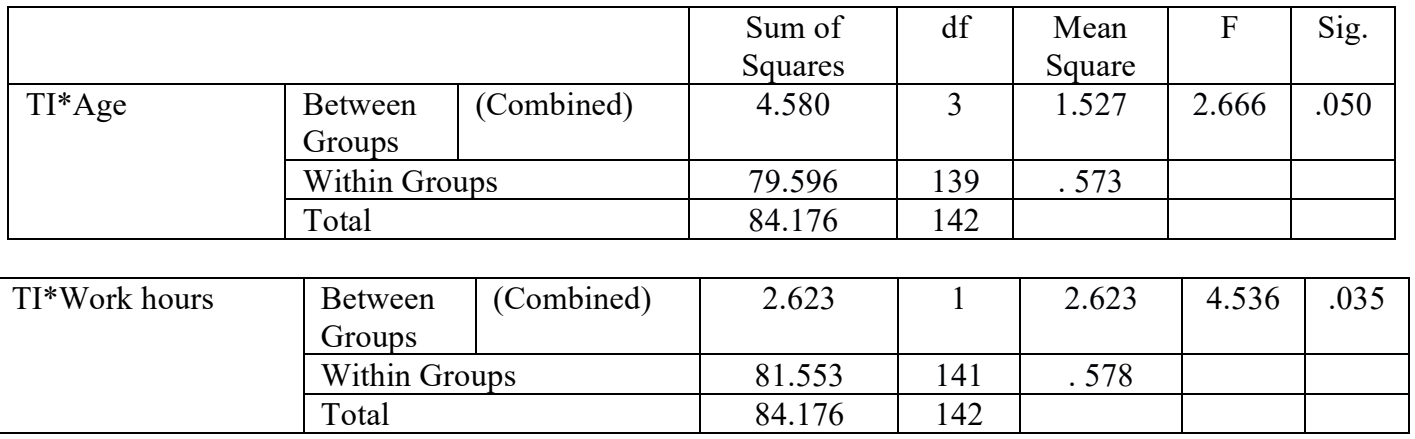

Note. TI, Turnover Intentions.

\subsection{Validity and Reliability Analysis}

A pilot study on five health-care staff was conducted to test feasibility of the questionnaire and the required time to fill it. As well as ensuring the questionnaire's content and validity by presenting the questionnaire to specialized arbitrators and made changes according to their opinion. Simple alterations were made by omitting or merging some of the questionnaire items which were not relevant to the participants.

The Cronbach's alpha was used to determine the internal reliability of the scales item (Nunnally, 1978). A minimum alpha, according to Nunnally and Berstein (1994), is 0.7. The Cronbach alpha estimated for job satisfaction was .833, work stress was .761 and turnover intention was .799. As the Cronbach's alpha in this study was excellent reliability with a coefficient of more than 0.7 , the scales were therefore considered to have 
adequate reliability in Saudi Arabia.

\subsection{Hypotheses Testing}

Results generated using Statistical Package for Social Science (SPSS). Hypotheses tested using regression analysis and correlation analysis. The regression coefficient of job satisfaction and work stress are shown in Table 4 . These two variables with $\mathrm{R}^{2}$ value which indicating its contribution for predicting the dependent variable. The adjusted $\mathrm{R}^{2}$ value is 0.168 which means that independent variables explains $16 \%$ of variance in turnover intentions of health care staff. As in Table 5.

Our first hypothesis that work stress will positively influence turnover intentions of health care staff is proven right from the results. The beta value for work stress is 0.539 with level of significance of .001 . Thus, our first hypothesis is accepted. Experiencing excessive workload, tense circumstances, role ambiguity, risky and complicated tasks, inexperienced coworkers, and unsatisfactory working conditions will significantly lower commitment. The same result was obtained in similar studies from (Han and Jekel, 2011; Shahnawaz and Jafri,2009; Ferdian, Luturlean, Zhafira and Izumi 2020; Liu, Zhu, Wu and Mao 2019; and Arshadi and Damiri, 2013).Table 3 shows the regression analysis results.

The beta value for job satisfaction is - 0.404 - with level of significant .001 which shows there is an effect of job satisfaction on turnover intention. Thus, our second hypothesis that job satisfaction will negatively influence turnover intentions of health care staff is accepted. Being satisfied with received benefits, having fair rules and procedures, good communication, clear goals, and receiving recognition, will distinctly decrease turnover intention. These results support previous studies from Cho, Lee, Mark, and Yun 2012; Pietersen and Oni 2014; Sukriket, 2015; and Huang, and Chih-Hao,2016).

Table4. Regression Analysis

\begin{tabular}{|c|c|c|c|c|c|}
\hline $\begin{array}{c}\text { Model } \\
1\end{array}$ & \multicolumn{2}{|c|}{ Unstandardized Coefficients } & $\begin{array}{c}\text { Standardized } \\
\text { Coefficients } \\
\text { Beta }\end{array}$ & $\mathrm{t}$ & Sig. \\
\hline Constant & 2.523 & 0.424 & & 5.953 & $<.001$ \\
\hline $\begin{array}{c}\text { Job } \\
\text { Satisfaction }\end{array}$ & $-0.404-$ & 0.091 & $-0.358-$ & $-4.428-$ & $<.001$ \\
\hline Work Stress & 0.539 & 0.131 & 0.333 & 4.126 & $<.001$ \\
\hline
\end{tabular}

Note. Dependent Variable: TI

Table5. Model Summary

\begin{tabular}{|c|c|c|c|c|}
\hline Model & $\mathrm{R}$ & $\mathrm{R}$ Square & $\begin{array}{c}\text { Adjusted R } \\
\text { Square }\end{array}$ & $\begin{array}{c}\text { Std. Error of the } \\
\text { Estimate }\end{array}$ \\
\hline 1 & $0.410^{a}$ & 0.168 & 0.156 & 0.70738 \\
\hline
\end{tabular}

Note. Predictors: (Constant), WS, JOBS

The third hypothesis that work stress has a significant and negative effect on employee's job satisfaction was rejected. As clarifies in Table 6 the regression coefficient of job satisfaction with $R^{2}$ value that indicating its contribution for predicting work stress as dependent variable. The adjusted $R^{2}$ value is 0.090 which means that job satisfaction explains $.09 \%$ of variance in work stress of health care staff as shown in Table 7 . The beta value of job satisfaction is 0.299 with level of significance of .001 . Thus, work stress has a significant positive effect on health care staff's job satisfaction. The result was different from most of the previous studies (Stanton, Bachiochi, Robie, Perez, and Smith, 2002 ; Venkataraman and Ganapthi 2013; and Saragih, et al. 2020). Health sector staff are highly stressed due to the nature of work. Moreover, several studies in the same field come up with the same result that work stress is significantly has a positive effect on health care staff's job satisfaction. Bytyqi, Reshani and Hasani, (2010) findings indicate that satisfied and committed employees will not guarantee to have a low level of work stress. Moreover, nurses' job satisfaction is influenced by job-related stress as the strongest predictor (Mansour, Taha, El-Araby and Younes 2014). In addition, Abu-Helalah, Jorissen, Niazand Al Qarni,(2014) found that about $97.0 \%$ of participants were highly stressed with a high rate of job satisfaction at National Guard Health Affairs working. They clarify some factors behind high-stress health-care workers including working on weekends, not being compensated for free time, being pressured to meet deadlines, and having insufficient staff to do the job. 
Table6. Regression Analysis

\begin{tabular}{|c|c|c|c|c|c|}
\hline $\begin{array}{c}\text { Model } \\
2\end{array}$ & \multicolumn{2}{|c|}{$\begin{array}{c}\text { Unstandardized Coefficients } \\
\text { Std.Error }\end{array}$} & $\begin{array}{c}\text { Standardized } \\
\text { Coefficients } \\
\text { Beta }\end{array}$ & $\mathrm{t}$ & Sig. \\
\hline Constant & 2.556 & 0.168 & & 15.190 & $<.001$ \\
\hline $\begin{array}{c}\text { Job } \\
\text { Satisfaction }\end{array}$ & 0.209 & 0.056 & 0.299 & 3.726 & $<.001$ \\
\hline
\end{tabular}

Note. Dependent Variable: WS

Table7. Model Summary

\begin{tabular}{|c|c|c|c|c|}
\hline Model & $\mathrm{R}$ & $\mathrm{R}$ Square & $\begin{array}{c}\text { Adjusted R } \\
\text { Square }\end{array}$ & $\begin{array}{c}\text { Std. Error of the } \\
\text { Estimate }\end{array}$ \\
\hline 2 & $0.299^{a}$ & 0.090 & 0.083 & 0.45613 \\
\hline
\end{tabular}

Note. Predictor: (Constant), JOBS

\section{Discussion and Conclusion \\ 5.1. Discussion:}

Two of the hypotheses were supported, that (H1) work stress positively influences turnover intention and (H2) job satisfaction negatively influence turnover intention. On the other hand, the third hypothesis was rejected which work stress negatively affect job satisfaction (H-3). The findings reveal that work stress and job satisfaction as antecedents of turnover intention and work stress has a positive effect on job satisfaction. Our finding of turnover antecedents proved previous studies' findings.

Work stress has a significant positive impact on the likelihood of turnover among health care staff in Saudi Arabia. This because the opportunities provided are less and the salaries of health staff are unified in the Kingdom of Saudi Arabia so, they don't have intention to leave otherwise they are waiting for retirement. Various studies using various sectors have discovered a positive relationship between work stress and turnover intention. Elci et al. (2010) conducted research in nine different industries in Turkey and discovered that work stress affects turnover intention positively. According to Tongchaiprasit and Ariyabuddhiphongs (2016) and Hwang et al (2014) in South Korea work stress can predict turnover intention. It is supported by Applebaum et al., (2010); Chen et al., (2010) studies. Second hypothesis was accepted that job satisfaction of health care staff has a significant negative correlation with turnover intention which is supported by the previous studies of (Pietersen and Oni, 2014; and Sukriket, 2015).

However, our findings revealed that the relationship between work stress and job satisfaction among healthcare staff is different from the literature presented. The third hypothesis (H3) work stress will significantly negatively affect health care staff's job satisfaction was rejected. The health-care system and promotion system in Saudi Arabia, which vary from those in other countries, are behind Saudi health care staff motives for being satisfied while they are highly stressed. In addition to comparatively high tax-free wages, Saudi Arabia offers other benefits such as free housing and paid tickets. According to Abu-Helalah, et al.(2014) benefits and incentive systems applied in the organization can be a reason behind the high satisfaction rate among the highly stressed employees. In addition, most of the respondents in this study were employed in the government health sector, thus, they often feel satisfied despite the pressure of work because of the job security provided by government employments and the Saudi Arabian labor law system, which always support Saudi employees.

\subsection{Conclusion:}

In conclusion, employees' needs should be recognized by the health sector, and a proper working environment should be provided. According to this research, health-care workers were stressed to some degree, but they were satisfied with their employment. Doctors and hospital staff are the health sector backbone. The doctors and medical personnel are responsible for the hospital's performance.

It is the responsibility of health sector training departments to provide basic training to their hospital personnel in order to reduce medical and non-medical staff stress and enhance the high level of job satisfaction. The health care centers and departments should also have a friendly and supportive work atmosphere for their medical personnel. By continued offering compensation and appraisal to their medical workers, they can easily enhance job satisfaction. 


\subsection{Implication and Limitations:}

This study examines the antecedents of turnover intention and the relationship between work stress and job satisfaction among health care staff in Saudi Arabia. This study is a good starting point for looking at the health sector's overall workforce in terms of turnover, job satisfaction and work stress in Saudi Arabia. However, there were some limitations in this research the sample size was small about 143 respondents, which may have restricted and increases the difficulty to draw conclusions based solely on this survey. So, a larger sample size may increase the confidence of the findings. Moreover, researchers' limited time and resources may affect research findings. As the research did not specify the sample to be Saudi only, some of the participants in this study may be nonSaudis who had already experienced homesickness, which interferes with the stressors. However, some of the respondents were excluded due to unseriousness and fairness in answering the questionnaire. So, other methods for collecting data can be used such as focus group to clarify the questionnaire to respondents.

\subsection{Recommendation and Future Research:}

Future research can investigate the factors of both job satisfaction and work stress that affect health care staff. Moreover, future research should investigate the positive effects of work stress on job satisfaction among health care staff to extend the existing literature. As well, this research provides a good starting point for looking at the wider workforce in terms of turnover, work stress, and job satisfaction in the Kingdom of Saudi Arabia. Further research is needed to examine the different dimensions of work stress that contribute to high turnover intention in health sector staff. Also, investigating the factors of both job satisfaction and work stress that affects health care staff especially the positive effects between the two variables to extend the existing literature. Different data entry should be used to enhance data accuracy such as interviews and focus groups to confirm respondent responses and lowering confusion among participants.

We recommend that future research should focus on methods for stress reduction among health-care workers, as well as the impact of high stress on staff performance. Health organizations should provide more desirable and competitive salaries and insurance packages for healthcare workers, as well as more efficient payment systems. In addition to providing training programs and developmental opportunities for healthcare workers, which will increase commitment levels between the worker and the organization. It is important to improve managerial procedures and communication means by enhancing workers' relationships between themselves and their supervisors, which will distinctly increase engagement levels.

\section{Acknowledgment}

We would like to express our sincere and gratitude to our research supervisor, Professor. Abdelmohsen Nassani for giving us the opportunity to do this research and providing us invaluable guidance and continuous support during data entry and management. His research vision, sincerity, and motivation have been deeply inspired us; we deeply appreciate his effort. We would also like to thank each participant of healthcare staff for their support and participation in the survey.

\section{References}

Applebaum, D., Fowler, S., Fiedler, N., Osinubi, O., Robson, M. (2010), The impact of environmental factors on nursing stress, job satisfaction, and turnover intention. The Journal of Nursing Administration, 40, 323.

Armstrong, M. (2006). A handbook of human resource management practice (10th ed.). London.

Cho, S., Lee, J., Mark, B., \& Yun, S. (2012). Turnover of new graduate nurses in their first job using survival analysis. Journal of Nursing Scholarship, 44(1), 63-70. doi:10.1111/j.1547-5069.2011.01428.X

Chen, X., Ran, L., Zhang, Y., Yang, J., Yao, H., Zhu, S., \& Tan, X. (2019). Moderating role of job satisfaction on TURNOVER intention and BURNOUT among workers in primary CARE Institutions: A cross-sectional study. doi:10.21203/rs.2.12008/v2

Chen, MF., Lin, CP., Lien, GY. (2010), Modeling job stress as a mediating role in predicting turnover intention. The Service Industries Journal, 31(8), 1327-1345.

Cote, R. (2017). A comparison of leadership theories in an organizational environment. International Journal of Business Administration, 8, 28-35. doi:10.5430/ijba.v8n5p28.

Conant, E. (2017). The impact of role conflict on job satisfaction of independent school athletic directors. Journal of Amateur Sport, 3(1), 1-26. Retrieved from https://journals.ku.edu/index.php/jams/article/view/5730

Diestel, S., Wegge, J., \& Schmidt, K. (2014). The Impact of Social Context on the Relationships between Individual Job Satisfaction and Absenteeism: The Roles of Different Foci of Job Satisfaction and Work Unit Absenteeism. Academy of Management Journal, 57(2), 353-382. doi:10.5465/amj.2010.1087. 
Ferdian, A., Luturlean, B. S., Zhafira, K. D., \& Izumi, N. K. (2020). The Impact of Work Stress on Turnover Intention in Indonesia: Is There A Mediation from Employee' Job Satisfaction?GATR Journal of Management and Marketing Review, 5(1), 31-40. doi:10.35609/jmmr.2020.5.1(3)

Fletcher, B.(C).). and Payne, R.L. (1980), "Stress and Work: A Review and Theoretical Framework, I", Personnel Review, Vol. 9 No. 1, pp. 19-29. https://doi.org/10.1108/eb055400

Grandey, A. A. (2000). Emotional regulation in the workplace: A new way to conceptualize emotional labor. Journal of occupational health psychology, 5(1), 95.

HAN, G. H., \& JEKEL, M. (2010). The mediating role of job satisfaction between leader-member exchange and turnover intentions. Journal of Nursing Management, 19(1), 41-49. doi:10.1111/j.13652834.2010.01184.x

Hoppock, R. (1935). Job satisfaction. New York: Harper and Brothers.

Huang, W., \& Chih-Hao, S. (2016). The mediating role of job satisfaction in the relationship between job training satisfaction and turnover intentions. Industrial and Commercial Training, 48(1), 42-52. doi:http://dx.doi.org.sdl.idm.oclc.org/10.1108/ICT-04-2015-0029

J. Hwang, J.J. Lee, S. Park, H. Chang, and S.S. Kim, “The Impact of Occupational Stress on Employee's Turnover Intention in the Luxury Hotel," International Journal of Hospitality \& Tourism Administration, vol. 15, no. 1 , pp. 60- 77, 2014.

J.M. Ivancevic and R. Konopaske, Human Resources Management, 12th Edition. New York: McGraw-Hill, 2013.

Khodabakhsh Ahmadi and Kolivand Alireza (2007). Stress and Job Satisfaction among Air Force Military Pilots. Journal of Social Sciences, 3 (3): 159-163.

Kreitner, R. and Kinicki, A. (2010), Organizational Behavior, 9th ed., McGraw-Hill/Irwin, New York, NY.

Lambert, E. G., Hogan, N. L., \& Keena, L. D. (2015). The Impact of Job Attitudes on Private Correctional Staff's Continuance and Affective Organizational Commitment. Journal of Applied Security Research, 10(1), 122.DOI: $10.1080 / 19361610.2015 .972260$

Liu, J., Zhu, B., Wu, J., \& Mao, Y. (2019). Job satisfaction, work stress, and turnover intentions among rural Health Workers: A cross-sectional study in 11 western provinces of China. BMC Family Practice, 20(1). doi:10.1186/s12875-019-0904-0

Maslow, A. H. (1970). Motivation and personality (2nd edition), New York, NY: Harper and Row.

Mcgrath, J.E. (1976). Stress and Behavior in Organizations, In M.D. Dunnette (Ed), 1976 Handbook of Industrial and Organizational Psychology. Counseling Psychological Stress, Palo Alto, CA.

M. Elci, I. Sener, S. Aksoy, and L. Alpkan, "The Impact of Ethical Leadership and Leadership Effectiveness on Employee's Turnover Intention: The Mediating Role of Work-Related Stress," Procedia - Social and Behavioral Sciences, vol. 58, pp. 289 - 297, 2010.

Ministry of health. Annual report, 2019, www.moh.gov.sa/Ministry/About/Documents/Annual-Report-144140.pdf.

O'Connell, M., \& Kung, M. C. (2007). The Cost of Employee Turnover. Industrial Management.

Pietersen, C., \& Oni, O. (2014). Comparing turnover drivers: differences and similarities in two economic sectors. Mediterranean Journal of Social Sciences, 5(7), 148-156. doi:10.5901/mjss.2014.v5n7p148.

P. Tongchaiprasit and V. Ariyabuddhiphongs, "Creativity and turnover intention among hotel chefs: The mediating effects of job satisfaction and job stress," International Journal of Hospitality Management, vol. 55, pp. 33-40, 2016.

Richardson, F.W. (2014). Enhancing strategies to improve workplace performance (Doctoral dissertation). Available from ProQuest Dissertations and Theses database. (UMI No. 3669117)

Salam, A. (2016, March). Job stress and job satisfaction among health care professionals. In Qatar Foundation Annual Research Conference Proceedings Volume 2016 Issue 1 (Vol. 2016, No. 1, p. HBOP2571). Hamad bin Khalifa University Press (HBKU Press).

Saragih, R., Prasetio, A. P., \& Luturlean, B. S. (2020). Examining the mediation of job satisfaction in the relationship between work stress and TURNOVER intention in textile company. GATR Journal of Management and Marketing Review, 5(2), 113-121. doi:10.35609/jmmr.2020.5.2(4)

Shafique, I., N. Kalyar, M., \& Ahmad, B. (2018). The Nexus of Ethical Leadership, job performance, and Turnover intention: The MEDIATING role of job satisfaction. Interdisciplinary Description of Complex Systems, 16(1), 71-87. doi:10.7906/indecs.16.1.5

Stanton, J. M., Bachiochi, P. D., Robie, C., Perez, L. M., \& Smith, P. C. (2002). Revising the JDI Work Subscale: Insights into stress and control. Educational and Psychological Measurement, 62(5), 877-895. DOI. http://dx.doi.org/10.1177/001316402236883.

Steinmetz, S., Vries, D. H., \& Tijdens, K. G. (2014). Should I stay or should I go? The impact of working time 
and wages on retention in the health workforce. Human Resources for Health, 12(1). doi:10.1186/14784491-12-23

Sukriket, P. (2015). The relationship between job satisfaction and turnover intention of Thai software programmers in Bangkok, Thailand. AU Journal of Management, 12(2). Retrieved from http://www.aujm.au.edu.

Shahnawaz, M.G. and Jafri, H. (2009), "Psychological capital as predictors of organizational commitment and organizational citizenship behaviour", Journal of the Indian Academy of Applied Psychology, Vol. 35, pp. 78-84.

Terera, S. R., \& Ngirande, H. (2014). The impact of rewards on job satisfaction and employee retention. Mediterranean Journal of Social Sciences, 5(1), 481.https://doi.org/10.5901/mjss.2014.v5n1p481

Troesch, L. M., \& Bauer, C. E. (2017). Second career teachers: Job satisfaction, job stress, and the role of selfefficacy.

Troesch, L. M., \& Bauer, C. E. (2017). Second career teachers: Job satisfaction, job stress, and the role of selfefficacy.

Venkataraman, P. S., \& Ganapathi, R. (2013). A Study of Job Stress on Job Satisfaction among the Employees of small Scale Industries. IOSR Journal of Business and Management (IOSR-JBM), 13(3), 18-22. http://iosrjournals.org/ iosr- jbm/papers/Vol13-issue3/C01331822.pdf.

Vroom, V. H. (1964). Work and motivation. New York: John Wiley and Sons.

Yang, H., Ju, Y., \& Lee, Y. (2016). Effects of job stress on self-esteem, job satisfaction, and turnover intention. Journal of Transnational Management, 21(1), 29-39. doi:10.1080/15475778.2016.1120613. 